\title{
Kinerja Guru Sekolah Dasar di Daerah Terpencil
}

\author{
Ana Merdekawaty \\ Universitas Samawa \\ ana.merdekawati90@gmail.com
}

\section{Informasi Artikel}

\section{Tanggal Publikasi}

31 Desember 2021

\section{Kata Kunci}

Motivasi

Efikasi Diri

Kinerja Guru

Daerah Terpencil

\begin{abstract}
Abstrak
Menjadi seorang guru di daerah terpencil tidak semudah yang dibayangkan. Memerlukan tekad dan semagat yang besar serta motivasi yang tinggi karena kondisi dearah terpencil sangat jauh berbeda dibandingkan dengan kota baik dari segi infrastruktur, sarana prasarana, media pembelajaran serta fasilitas pendukung lainnya. Namun bagi guru yang memiliki motivasi dan keyakinan yang tinggi akan kemamapuan dirinya, hal tersebut justru menjadi tantangan yang memacu dirinya untuk terus bekerja keras menjalankan tugasnya mencerdaskan anak bangsa. Penelitian ini bertujuan melihat pengaruh motivasi dan efikasi diri terhadap kinerja guru sekolah dasar di daerah terpencil. Responden penelitian adalah guru SD yang tersebar pada tujuh SD di Kecamatan Orong Telu Kabupaten Sumbawa. Analisis data menggunakan regresi linier berganda dengan kuisioner sebagai alat pengumpulan data. Hasil penelitian menunjukkan bahwa terdapat pengaruh positif dan signifikan baik secara parsial maupun secara simultan antara motivasi dan efikasi diri terhadap kinerja guru SD di daerah terpencil. Berdasarkan hasil uji statistik diketahui nilai Fhitung $=50,508$ dimana $F_{\text {tabel }}=3,12$ sehingga $F_{\text {hitung }}>F_{\text {tabel }}$ dengan signifikansi $p=0,000<0,05$ yang berarti motivasi dan efikasi diri secara simultan berpengaruh terhadap kinerja guru. Dengan demikian maka, hipotesis yang diajukan dalam penelitian ini dinyatakan diterima.
\end{abstract}

This is an open access article under the CC - BY license.

\section{PENDAHULUAN}

Daerah terpencil adalah daerah yang sulit dijangkau baik melalui transportasi darat maupun laut, serta memiliki keterbatasan sarana dan prasarana sosial dan ekonomi. Kesulitan akses kedareah terpencil disebabkan keadaan geografis. Sebagian besar kondisi geografis daerah terpencil berupa kepulauan, pegunungan, daratan, hutan dan rawa. Kondisi ini menyebabkan daerah ini menjadi terisolir. Suatu darah dapat dikatakan terpencil, apabila memenuhi dua persyaratan, yaitu kurangnya sarana prasarana transportasi darat, laut maupun udara, serta terbatasnya jumlah sarana prasarana sosial dan ekonomi. Menurut PP. No.57 tahun 2005, Desa adalah kesatuan masyarakat hukum yang memiliki batas-batas wilayah yang berwenang untuk mengatur dan mengurus kepentingan masyarakat setempat, berdasarkan asal-usul dan adat istiadat setempat yang diakui dan dihormati dalam sistem Pemerintahan Negara Kesatuan Republik Indonesia. Desa bukanlah bawahan kecamatan, karena kecamatan merupakan bagian dari perangkat daerah kabupaten/kota, dan desa bukan merupakan bagian dari perangkat daerah. Berbeda dengan Kelurahan, Desa memiliki hak mengatur wilayahnya lebih luas. Namun dalam perkembangannya, sebuah desa dapat ditingkatkan statusnya menjadi kelurahan.

Sedangkan kategori Sekolah terpencil, yaitu sekolah yang terketak di daerah terpencil yang sulit dijangkau dan lokasinya jauh dari pusat kota. Sekolah terpencil indentik dengan terbatasnya fasilitas pendukung pembelajaran, seperti buku, media pembelajaran, alat peraga, alat laboratorium dan alat-alat olahraga, Bahkan 
pasokan listik yang terbatas dan tidak adanya jaringan telepon dan internet. Walaupun ada terkadang signal sangat buruk sering mengalami gangguan (Muhaimin dan Kristiawan, 2019).

Untuk menjadi seorang guru di daerah terpencil tidaklah mudah. Memerlukan tekad dan semagat yang besar serta motivasi yang tinggi karena kondisi dearah terpencil sangat jauh berbeda dibandingkan dengan kota baik dari segi infrastruktur, sarana prasarana, media pembelajaran serta fasilitas pendukung lainnya. Jadi, bisa dikatakan hanya guru yang bermental baja yang dapat bertahan mengajar di daerah tersebut.

Guru merupakan profesi mulia yang menempati kedudukan terhormat di mata masyarakat. Keberadaan guru memberikan andil besar terhadap peningkatan kualaitas Indeks Pembangunan Manusia (IPM) dan merupakan posisi strategi dalam memajukan suatu bangsa. Gurulah yang mendidik anak bangsa menjadi anak yang berkepribadian mulia dan membentuk jiwa dan watak anak didik. Sealin itu, guru adalah sosok panutan yang berada di sekolah dan masyarakat karena ilmu yang dimilikinya. Bahkan ada yang menyamakan guru sebaia ulama yang dihormati dan disegani oleh masyarakat (Hayun, 2015).

Salah satu yang menjadi tolok ukur keberhasilan guru SD dalam mengajar adalah kinerja mereka. Kinerja guru merupakan kemmapuan dan keberhasilan dalam melaksanakan tugasnya dalam kegiatan belajr mengajar (Supardi, 2013). Sejalan dengan pendapat Mangkunegara (2005) bahwa kinerja meruapakan hasil kerja yang diacapai seseorang dalam melaksanakan tugas yang didasarkan atas kecakapan, pengalaman dan kesungguhan serta waktu. Kinerja menunjukkan tingkat keberhasilan dalam mencapai tujuan dan standar yang telah ditetapkan (Yamin, 2010). Seseuai dengan Satndar Nasional Pendidikan pasal 28 ayat 3 menyebutkan kompetensi yang harus dimiliki guru yaitu kompetensi pedagogik, profesional, sosial dan kepribadian. Peran guru sangat besar dalam duia pendidikan. Ia merupakan tenaga inti yang bertanggung jawab dalam pelaksanaan kegiatan belajar mengajar. Sehingga guru diharapkan memiliki dedikasi, loyalitas, tanggung jawab, dan motivasi yang tinggi dalam melaksanakan tugasnya.

Ada banyak faktor yang mempengaruhi tinggi rendahnya kienrja guru khususnya di daerah terpencil, diantaranya motivasi kerja dan efikasi diri yang dimiliki seorang guru. Dalam menjalankan tugasnya mengabdikan diri di daerah terpencil tentu sangat tidak mudah. Karena kita ketahui bersama bahwa terdapat banyak tantangan dan rintangan yang akan mempersulit guru dalam melaksanakan tugas yang diberikan kepadanya. Bahkan hal ini membuat banyak guru yang tidak bersedia dan menolak untuk ditempatkan di daerah terpencil, juga tidak sedikit guru yang mengajukan pindah tugas ke kota atau ke tempat lainnya karena tidak mampu bertahan dengan keadaan di daerah terpencil yang serba kekurangan. Namun, ada juga guru yang bertahan sampai bertahun-tahun mengabdikan diri menjadi seorang guru. Hal ini dilandasi karena motivasi dan keyakinan yang kuat bahwa ia mampu melaksanakan tugasnya dengan baik ditengah kesulitan-kesulitan yang dihadapinya.

Pada dasarnya setiap aktivitas manusia dilandasi oleh adanya dorongan untuk mencapai tujuan atau terpenguhi kebutuhan. Daya pendorong inilah yang dinamakan motivasi, yaitu sesuatu yang mendorong seseorang untuk menunjukan perilaku tertentu. Kondisi atau energi yang menggerakan diri karyawan yang terarah atau tertuju untuk mencapai tujuan organisasi perusahaan. Motif tidak dapat diamati secara langsung, tetapi dapat diinterprestasikan dalam tingkah lakunya berupa rangsangan, dorongan, atau pembangkit tenaga munculnya suatu tingkah laku tertentu (Zaenuri, 2015). Motivasi adalah konsep yang digunakan untuk menjelaskan inisiasi, arah dan intensitas perilaku individu. Motivasi juga dapat diartikan dorongan, rangsangan, pembangkit tenaga bagi terjadinya suatu perbuatan/perilaku (Sarwono, 2012). Sedangkan Sardiman (2011) menyatakan bahwa motivasi adalah motif yang sudah menjadi aktif. Artinya semakin banyak motif yang ada dalam diri seseorang, maka akan semakin kuatlah motivasinya dalam bertindak (Azwar,2009).

Terdapat banyak penelitian tentang hubungan motivasi dengan kinerja, diantaranya penelitian Drake et al. (2007); Harwiki (2012); Javadi et al. (2012); Yun Gou et al. (2014), hasil penelitian mereka menunjukkan bahwa motivasi guru memberikan pengaruh yang kuat terhadap kinerja guru. Namun, ada pula hasil yang berbeda yang menunjukkan kinerja tidak dipengaruhi oleh motivasi. Seperti penelitian yang dilakukan Devi (2009), bahwa motivasi tidak berpengaruh terhadap kinerja. Variabel dominan yang mempenagruhi kinerja adalah penelitian dan pendidikan. Dari hasil-hasil penelitian di atas masih terjadi perbedaan hasil penelitian pengaruh motivasi terhadap kinerja guru, sehingga perlu dilakukan penelitian lebih lanjut. 
Selain motivasi, berdasarkan literatur dan hasil penelitian sebelumnya, kinerja juga dipengaruhi oleh efikasi diri. Menurut Bandura dalam (Merdekawti, 2019) efikasi diri merupakan keyakinan atau kepercayaan seseorang akan kemampuan untuk sukses dalam melakukan sesuatu. Guru dengan efikasi diri yang tinggi akan mampu bertahan dalam berbagai situasi dan kondisi serta tetap memiliki keyakinan dan pengharapan yang etguh dan gigih dalam melaksnakan tugas mengajar. Efikasi diri merupakan penilaian diri terhadap kemampuan atau kompetensinya untuk melakukan suatu tugas, mencapai tujuan, atau mengatasi hambatan dalam pekerjaan. Efikasi diri memiliki pengaruh yang baik dalam menentukan keberhasilan yang akan dicapai oleh seorang guru, karena dengan efikasi diri yang tinggi akan memberikan inisiatif dan ketekunan untuk meningkatkan usaha dan kemampuan seorang untuk mendapatkan apa yang diinginkannya.

Efikasi diri berkaitan dengan kebiasaan hidup manusia ynag didasarkan pada prinsip karakter seperti integritas, kesetiaan, kerendahan hati, kegigihan, tekad kuat, keberanian, kejujuran, keadilan, kesabaran, kerajinan, pantang menyerah, keuletan, kesederhanaan dan kesopanan yang seharusnya dikembangkan di dalam diri seseorang tanpa pemaksaan. Efikasi mengacu pada keyakinan sejauhmana individu memperkirakan kemampuan dirinya dalam melaksanakan tugas untuk mencapai hasil terbaik dari pekerjaannya. Keyakinan ini meliputi kepercayaan diri, kecerdasan, kapasitas kognitif, dan kemampuan bertindak serta mengambil keputusan dalam situasi sulit dan penuh tekanan. Hal senada juga disampaikan oleh Kreiner \& Kinicki (2007), efikasi diri adalah wujud keyakinan seseorang bahwa dirinya pasti berhasil mencapai tujuan yang diinginkan.

Salah satu hasil proses kognitif yang harus dikembangkan seseorang agar dapat bertahan dakam kondisi sehat, seimbang dan tidak terganggu dengan ketikpusan kerja dalah efiksi diri. Hal ini menunjukkan pentingnya peran efikasi diri dalam menghadapi permaslahan yang mungkin muncul setiap saat dalam melaksanakan suatu pekerjaan. Merdekawati (2019) mengatakan bahwa efikasi diri dapat membawa pada perilaku yang berbeda diantara individu dengan kemampuan yang sama. Hal ini disebabkan karena adanya pengaruh perbedaan pilihan, tujuan, pengatasan masalah dan kegigihan dalam berusaha.

Individu dengan efikasi tinggi percaya bahwa mereka mampu melakukan sesuatu utuk merubah hambatan disekitarnya. Bagi mereka kesulitan yang ada bukanlah penghalang yang dapat menghentikan langkah dan upaya mereka untuk mendapatkan apa yang mereka inginkan. Namun sebaliknya bagi individu yang efikasinya rendah, mereka mudah putus asa dan menyerah, karena mereka tidak memiliki keyakinan yang kuat dalam diri bahwa mereka bisa dan mampu melalui kesulitan yang ada. Dalam situasi yang sulit orang dengan efikasi yang rendah cenderung mudah menyerah, sedangkan orang dengan efikasi diri yang tinggi akan berusaha lebih keras untuk mengatasi tantangan yang ada. Hal ini membuktikan bahwa efikasi memainkan peranan yang sangat penting dalam menyelesaikan pekerjaan yang menantang dan membutuhakn kegigihan gunamencapai tujuan yang telah ditentukan Monika (2017). Begitu pula dengan seorang guru dengan efikasi diri yang tinggi, dia memiliki keyakinan yang kuat bahwa seberat apapun tantangan dan kesulitan dalam mengajar khususnya di daerah terpencil, ia pasti mampu melaluinya. Keyakinan kuat yang ada pada diri inilah yang mendorongnya untuk berpikir, berusaha, dan bergerak melakukan perubahan guna mencapai tujuan pendidikan yang telah diamanahkan kepadanya.

Fenomena ini menunjukkan bahwa guru dengan efikasi diri yang tinggi mengindikasikan bahwa kinerjanya juga tinggi. Efikasi diri ynag tinggi akan mendorong meningkatnya kinerja dalam melaksanakan tugas yang diberikan kepadanya. Hal ini sesuai dengan hasil penelitian Rahmi et al. (2012); Luszczynska et al. (2006); Cherian \& Jacob (2014), bahwa self Eficacy guru memberikan penegruh positif terhadap kinerja. Namun hasil berbeda ditunjukkan oleh Khan (2013), ia menyatakan bahwa self Eficacy tidak memberikan pengaruh terhadap kinerja. Perbedaan hasil penelitian ini menarik untuk dikaji lebih dalam lagi.

Fenomena yang terjadi di daerah terpencil yang mana kita ketahui bersama terdapat banyak hambatan dan tantangan yang dialami oleh guru dalam mengabdikan diri guna mencerdaskan anak bangsa. Beberapa kendala yang dahapi guru yang mengajar di daerah terpencil dintaranya, keterbatasan fasilitas pembelajaran seperti alat-alat peraga, media pembelajaran, listrik dan jaringan internet, lokasi sekolah yang jauh dan jalan yang rusak parah dan banyak lagi kendala-kendala lainnya. Hal ini tentu sangat mempengaruhi motivasi dan kinerja guru dalam pelaksanaan pembelajaran di sekolah. Berdasarkan permasalahan yang terjadi di lokasi penelitian, maka perlu dilakukan riset mengenai apakah ada pengaruh motivasi dan efikasi diri terhadap kinerja guru SD di daerah terpencil. 
Berdasarkan hal tersebut, maka rumusan masalah dari penelitian ini adalah "apakah motivasi dan efikasi diri berpengaruh terhadap kinerja guru SD di daerah terpencil?". Sehingga tujuan dari penelitian adalah menganalisis pengaruh motivasi dan dan efikasi diri terhadap kinerja guru SD di daerah terpencil. Adapun kerangka konseptual dari penelitian ini dapat dilihat pada gambar 1.

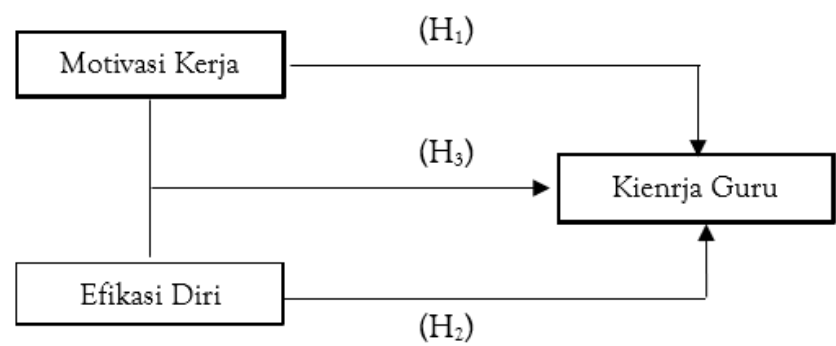

Gambar 1 Kerangka Konseptual Penelitian

$\mathrm{H}_{1}=$ motivasi berpengaruh terhadap kinerja

$\mathrm{H}_{2}=$ efikasi diri berpengaruh terhadap kinerj guru

$\mathrm{H}_{3}=$ motivasi dan efikasi diri berpengaruh terhadap kinerj guru

\section{METODE PENELITIAN}

Berdasarkan hubungan antara variabel bebas dan terikat, maka penelitian ini merupakan penelitian asosiatif, yaitu penelitian yang bertujuan untuk mengetahui hubungan dua variabel atau lebih. Hubunagn yang digunkan dalam penelitian ini adlah hubungan kausal atau hubungan sebab akibat. Sampel sekaligus responden dalam penelitian ini dalah guru SD di kecamatan Orong Telu Kabupaten Sumbawa berjumlah 41 orang guru SD yang tersebar dalam tujuh SD, yaitu guru SDN Kelawis, SDN 1 Sebeok, SDN 2 Sebeok, SDN Harapan Jaya, SDN Pelita Masa, SDN Senawang dan SDN Kopo. Sumber data berupa data primer diperoleh secara langsung dari responden melalui penyebaran angket/kuesioner. Alternatif jawaban kuesioner mengacu pada slaka likert dengan lima alternatif jawaban.

Sedangkan untuk uji instrumen penelitian menggunakan uji validitas dan uji reliabilitas. Uji validitas menggunakan korelasi product moment dari pearson. Kuesioner dikatakan valid jika setiap item pernyataan memiliki keterkaitan yang tinggi. Sedangkan uji reliabilitas menunjukkan konsistensi suatu alat ukur di dalam mengukur gejala yang sama. Suatu variabel dikatan reliabel jika nilai cronbach alpha $(\alpha)>0,6$. Uji asumsi klasik yang digunakan adalah uji normalitas, uji multikolinearitas, uji heteroskedastisitas dan autokorelasi. Sedangkan uji hipotesis menggunakan analisis regresi berganda, uji t dan uji F. Analisa regresi berganda digunakan untuk mengetahui pengaruh variabel indipenden terhadap variabel dependen. Formulasi yang dihasilkan dalam bentuk $\mathrm{Y}=\mathrm{a}+\mathrm{b} 1 \mathrm{X} 1+\mathrm{b} 2 \mathrm{X} 2+\mathrm{b} 3 \mathrm{X} 3+\mathrm{e}$. Uji t digunakan untuk mengetahui derajat keyakinan antara variabel yang diteliti secara parsial. Uji F digunakan untuk mengetahui pengaruh variabel yang diteliti secara simultan.

\section{HASIL DAN PEMBAHASAN}

\section{Analisis Regresi Linier Berganda}

Analisis Regresi Linier Berganda digunakan untuk mengukur besarnya pengaruh motivasi dan efikasi diri terhadap kinerja guru SD di daerah terpencil. Setelah dilakukan pengolahan data diperoleh hasil seperti pada tabel 1.

Tabel 1. Hasil Analisis Regresi Berganda

\begin{tabular}{cccccc}
\hline \multicolumn{7}{c}{ Coeficient } \\
\hline \multirow{2}{*}{ Model } & \multicolumn{7}{c}{ Unstandardized Coefficients } & Standardized Coefficients & \multirow{2}{*}{ T } & \multirow{2}{*}{ Sig. } \\
\cline { 2 - 4 } & $\mathrm{B}$ & Std. Error & Beta & 12.334 & .000 \\
\hline (Constant) & 40.161 & 3.256 & & 2.538 & .013 \\
Motivasi & .276 & .109 & .432 & 2.018 & .047 \\
Efikasi Diri & .274 & .136 & .343 & \\
\hline
\end{tabular}

Berdasarkan hasil perhitungan pada tabel di atas, dapat dibuat persamaan sebagai berikut: 
$Y=40,161+0,276 X 1+0,274 X 2$.

Keterangan:

$\mathrm{Y} \quad=$ Kinerja Guru

$\mathrm{X}_{1} \quad=$ Motivasi

$\mathrm{X}_{2}=$ Efikasi Diri

$\mathrm{E}=$ error

Dari persamaan regresi, dapat diketahui apabila terjadi peningkatan setiap satu satuan pada motivasi dan efikasi diri, maka semakin meningkat juga kinerja guru.

\section{Uji Hipotesa}

Berdasarakan hasil uji t statistik, diketahui bahwa motivasi dengan nilai thitung $=2.538$ dan signifikasi $\mathrm{p}=$ $0,000<0,05$ serta efikasi diri dengan nilai $t_{\text {hitung }}=2.018$ dengan signifikasi $p=0,013<0,05$ dimana $t_{\text {tabel }}=1,991$ berdasarkan hasil tersebut maka $t_{\text {hitung }}>t_{\text {tabel }}$, berarti motivasi dan efikasi diri berpengaruh positif dan signifikan secara parsial terhadap kinerja guru SD di Daerah terpencil. Hasil uji F juga menunjukkan bahwa motivasi dan efikasi diri berpengaruh positif dan signifikan secara simultan terhadap kinerja guru SD di daeraj terpencil. Hal ini dibuktikan melalui uji $F$ statistik yang menunjukkan $F_{\text {hitung }}>F_{\text {tabel }}(50,508>3,12)$ dengan taraf signifikansi $p=0,000<0,05$. Dengan demikian maka hipotesisi minor yang diajukan dalam penelitian ini dinyatakan dapat diterima. Koefisien determinasi $\left(\mathrm{R}^{2}\right)$ sebesar $=, 571$. Yang bermakna bahwa kinerja guru mampu dijelaskan pengaruhnya sebanyak 57,1\% oleh motivasi dan efikasi diri. Sedangkan sisa 42,9\% dijelaskan oleh variabel lain yang tidak diteliti dalam penelitian ini.

Tabel 2 Hasil Uji Hipotesis

\begin{tabular}{llllll}
\hline Variabel & thitung $_{\text {tabel }}$ & Keputusan & kesimpulan & Sig \\
\hline Motivasi & 2,538 & 1,991 & $\begin{array}{l}\text { Menolak } \mathrm{H}_{0} \\
\text { menerima Ha }\end{array}$ & signifikan & 0,013 \\
Efikasi Diri & 2,018 & 1,991 & $\begin{array}{l}\text { Menolak H } \\
\text { menerima Ha }\end{array}$ & signifikan & 0,047 \\
\hline
\end{tabular}

\section{Pengaruh Motivasi dan Efikasi Diri terhadap Kinerja Guru}

Hasil temuan analisis ini memberikan informasi bahwa motivasi kerja berpengaruh positif dan signifikan terhadap kinerja guru SD di daerah terpencil. Dilihat dari hasil uji statistik bahwa thitung $>t_{\text {tabel }}$, yaitu 2.538 $>1,991$ maka motivasi berpengaruh secara parsial terhadap kinerja guru SD di Daerah Terpencil. Motivasi merupakan energi atau kekuatan besar yang mendorong guru dalam melakukan kegiatan berkaitan dengan tugasnya sebagai pengajar sekaligus pendidik. Motivasi menjadi pendorong yang mangakibatkan guru mau dan rela untuk mengerahkan kemampuan dalam bentuk keahlian atau keterampilan, tenaga dan waktunya untuk menyelenggarakan berbagai kegiatan yang menjadi tanggung jawabnya dan menunaikan kewajibannya, dalam rangka pencapaian tujuan. Sebesar apapun rintangan dan hambatan yang dihadapi dalam pelaksanaan tugasnya sehari-hari, namun jika motivasi guru tersebut tinggi dan kuat maka hambatan tersebut pasti bisa dilalui dengan baik. Guru pun dapat menjalankan tugasnya dengan optimal. Sehingga apabila motivasi mengajar guru tinggi, maka hal ini akan berpengaruh pada kinerjanya, yaitu kinerja akan meningkat seiring dengan meningkatnya motivasi.

Hasil penelitian ini relevan dengan penelitian yang dilakukan oleh Sakiman (2019), yang menyimpulkan bahwa terdapat peran positif antara motivasi kerja terhadap kinerja guru Taman Kanak-Kanak di Kabupaten Kulon Progo Utara. Peran positif menujukkan semakin tinggi motivasi kerja, kinerja semakin meningkat. Keadaan ini dibuktikan dengan semakin terpunuhinya kebutuhan guru seperti, kebutuhan mempertahankan hidup, kebutuhan akan rasa aman, kebutuhan sosial, kebutuhan akan penghargaan, kebutuhan untuk berprestasi dan kebutuhan akan aktualisasi diri di sekolah maka guru akan berusaha meningktkan kinerja.

Hal ini juga diperkuat dengan hasil penelitian Muhaimin dan Kristiawan (2019), bahwa motivasi mengajar sangat berperan penting terhadap kinerja guru. Menurutnya, peran motivasi intrinsik dan ekstrinsik guru mengajar di sekolah terpencil diantaranya: 1)motivasi berperan sebagai pendorong keamuan dan keinginan 
seseorang; 2) motivasi yang besar dan kuat akan menimbulkan rasa mealkukan dengan terarah, sunguh-sungguh dan penuh semangat sehingga kemungkinan untuk berhasil lebih besar; 3) motivasi mendorong seseorang melakukan sesutu dengan baik dan benar. Dengan beberapa hasil penelitian yang relevan di atas, menunjukkan dengan jelas bahwa motivasi sangat berperan penting dan berpengaruh besar bagi tinggi rendahnya kinerja seseorang. Motivasi erat kaitannya dengan kinerja guru untuk mengajar dan bertahan di daerah terpencil. Motivasi kerja guru tidak hanya bersumber dari eksternal, tetapi secara internal motivasi kerja guru dapat bersumber dari dalam diri guru itu sendiri, oleh karena itu agar kinerja guru tinggi, maka diharapkan kepada semua guru baik di kota terlebih lagi guru di pelosok atau daerah terpencil agar tetap semangat menjalankan tugas mulianya mendidik anak bangsa.

Mengacu pada hasil analisis data, efikasi diri juga berpengaruh positif dan signifikan terhadap kinerja guru. Ini dapat dibuktikan dari hasil uji $t$ yang menunjukkan $t_{\text {hitung }}>t_{\text {tabel }}$ yaitu $(2,018>1,991)$. Artinya, efikasi diri secara parsial berpengaruh terhadap kinerja guru SD di Daerah terpencil. Hal ini bermakna bahwa, jika terjadi kenaikan pada efikasi diri seorang guru, maka akan diikuti oleh kenaikan kinerja. Hasil penelitian ini relevan dengan pernyataan Aslamiyah (2020), yang mengemukakan faktor yang mempengaruhi kinerja seseorang antara lain sikap (meliputi keyakinan, perasaan, dan perilaku), keterlibatan kerja, partisipasi, dan penampilan. Keseluruhan faktor ini mencakup motivasi dan efikasi diri.

Efikasi diri merupakan ekspektasi positif yang diyakini tentang kemampuan diri dalam mencapai sesuatu. Hal ini juga sesuai dengan pendapat Adicondro (2011) yang menyatakan jika seseoranh memilki efikasi diri tinggi maka akan memiliki keyakinan mengenai kemampuan dalam menyelesaikan tugas belajr yang diperlukan untuk mencapai target tertentu dalam berbagai bentuk dan tingkat kesulitan. Dan berlaku sebalinya jika seseorang dengan efikasi diri rendah maka keamauan dan kemampuan untuk meyelesaikan tugas juga menurun. Oleh karena itu seorang guru yang memiliki sikap positif terhadap tugasnya maka akan dapat menjalankan tugas dan fungsinya sebagai guru dengan penuh tanggung jawab.

Seorang guru yang memiliki efikasi diri yang tinggi, maka baginya kesulitan yang dialami dalam pelaksanaannya sebagai guru di daerah terpencil justru dianggap sebagai pemacu semangat untuk bekerja lebih giat lagi. Karena ia memilki sikap positif dan keyakinan yang kuat bahwa ia mampu melaksanakan tugas yang telah diamanahkan kepadanya. Dengan efikasi diri yang tinggi tugas yang dirasakan sulit akan dapat dihadapi dengan berbagai situasi melalui keyakinan, kegigihan dan kemampuannya sendiri.

Guru dengan efikasi yang tinggi maka akan mempunyai kinerja yang tinggi pula. Temuan ini diperkuat dengan hasil penelitian Sjamsuri dan Muliani (2019), yang meneliti pengaruh efikasi diri terhadap kinerja guru di SMA PGRI 3 Jakarta. Hasil penelitian menunjukkan bahwa efikasi diri berpengaruh langsung terhadap kinerja guru di SMA PGRI. Penelitian ini juga menunjukkan bahwa guru dengan tingkat pendidikan lebih tinggi dengan pengalaman kerja lebih lama memiliki efikasi diri lebih tinggi. Guru yang efikasi diri tinggi percaya bahwa mereka mampu mengelola kelas dengan baik, mampu memberikan perhatian dan kesabaran dalam mendidik peserta didik dan memiliki keyakinan bahwa mereka dapat melaksanakan tugasnya denga baik. Seperti yang diungkap oleh Caprara et al dalam Sjamsuri dan Muliani (2019) bahwa teachers with high self-efficacy beliefs are more likely than teachers with a low sense of self-eficacy to implement didactic innovations in the classroom and to use classrooms management approacher and adequate teaching methods that encourage students autonomy. Jadi ketika guru menghadapi peserta didik yang mengalami kesulitan belajar, tidak aktif dikelas, fasilitas pembelajaran yang terbatas, bagi guru yang efikasi dirinya tinggi berusaha keras untuk mengatasinya sehingga kinerjanya meningkat.

Merujuk dari teori dan hasil penelitian di atas, jelaslah bahwa efikasi diri berpengaruh terhadap kinerja guru. Maka, hipotesis minor yang diajukan dalam penelitian ini teruji kebenarannya, hal ini menunjukkan ada pengaruh yang signifikan antara motivasi kerja dan efikasi diri terhadap kinerja guru, yang berarti semakin tinggi motivasi kerja dan efikasi diri akan semakin tinggi pula kinerja guru begitu pula sebaliknya, semakin rendah motivasi kerja dan efikasi diri maka rendah pula kinerja guru.

Hasil lainnya yang diperoleh dari penelitian ini, yaitu para guru sekolah dasar di Kecamatan orong telu kabupaten Sumbawa yang tergolong daerah terpencil memiliki motivasi, efikasi diri dan kinerja yang tergolong tinggi namun tetap perlu untuk ditingkatkan lagi.

\section{KESIMPULAN}


Berdasarkan hasil penelitian yang telah dilakukan dapat ditarik kesimpulan bahwa motivasi dan efikasi diri berpengaruh positif dan signifikan secara parsial dan simultan terhadap kinerja guru SD di daerah terpencil. Sehingga direkomendasikan bagi guru agar selalu meningkatkan motivasi kerja dan tingkatkan efikasi diri dalam melaksanakan tugas mencerdakan anak bangsa. Selain itu, pemerintah dan semua steakholder terkait perlu memberikan perhatian serius demi peningkatan mutu pendidikan di daerah terpencil.

\section{Ucapan Terima Kasih}

Terimakasih kepada kepala sekolah dan Guru di lingkup Sekolah Dasar kecamatan Orong Telu atas partisipasi dan bantuannya dalam memberikan data penelitian, terimasih juga kepada enumerator yg membantu dalam proses pengumpulan data sehingga penelitian ini dapat terselesaikan.

\section{Daftar Pustaka}

Adicondro, N. \& Purnamasari, A. (2011). Efikasi Diri, Dukungan Sosial Keluarga dan Sefl Regulated Learning pada Mahasiswa Kelas VIII. Jurnal Humanitas. 8(1): 17-27. http://journal.uad.ac.id/index.php/HUMANITAS/article/view/448/290

Aslamiyah., S. Lahmuddin., Effendy.,S. (2020). Pengaruh Motivasi dan Efikasi Diri terhadap Kinerja Guru SEkolah Taman Kanak-Kanak di Kecamatan Medan Area. Tabulrasa:Jurnal Ilmiah Magister Psikologi. 2(2):143-15. http://repository.uma.ac.id/handle/123456789/13716

Azwar., S. (2009). Penyusunan Skala Psikologi. Yogyakarta: Pustaka Pelajar.

Hayun, M., (2015) Pengaruh Efikasi Diri Terhadap Motivasi Menjadi Guru Pada Mahasiswa PGSD $\begin{array}{llll}\text { UMJ. Jurnal Teknodik } & \text { 57-68. }\end{array}$ https://jurnalteknodik.kemdikbud.go.id/index.php/jurnalteknodik/article/view/146

Mangkunegara, A.P. (2005). Manajemen Sumber Daya Manusia Perusahaan. Bandung: PT. Remaja Rosdakarya.

Merdekawati, A., Fatmawati. (2019). Pengaruh Kemandirian Belajar Dan Efikasi Diri Terhadap $\begin{array}{lllll}\text { Pemahaman Akuntansi } & \text { Siswa. Edunomic. } & \text { 95-101 }\end{array}$ http://jurnal.ugj.ac.id/index.php/Edunomic/article/view/1862

Monika, A. (2017). Peran Efikasi Diri dan Motivasi Belajar dalam Meningkatkan Hasil Belajar Siswa Sekolah Menengah Kejuruan. Jurnal Pendidikan Manajemen Perkantoran, 1(1), 110-117. https://ejournal.upi.edu/index.php/jpmanper/article/view/8111

Muhaimin dan Kristiawan. (2019). Resistensi Guru Mengajar Di Daerah Terpencil. Prosiding Seminar Nasional Pendidikan Program Pascasarjana Universitas PGRI Palembang, 1-12. https://jurnal.univpgri-palembang.ac.id/index.php/Prosidingpps/article/view/2581

Kreitner, R. dan Kinicki, A. (2007). Organizational Behavior. 7th edition. New York: McGraw-Hill

Sakiman. (2019). Peran motivasi kerja dan kepuasan kerja terhadap kinerja guru taman kanak-kanak non-PNS Kabupaten Kulon Progo. Jurnal psikologi terapan dan pendidikan.1(1):30-44

http://journal.uad.ac.id/index.php/Psikologi/article/view/15130

Sardiman, A. M. (2011). Interaksi dan Motivasi Belajar Mengajar. Jakarta: Rajawali Press

Sjamsuri., A \& Muliyani., N (2019), Pengaruh Efikasi Diri terhadap Kinerja Guru Di SMA PGRI 3 Jakarta. Faktor Jurnal Ilmiah Kependidikan 6(1):1-6. 3file:///C:/Users/LENOVO 1/AppData/Local/Temp/3094-9945-1-PB.pdf

Sarwono., SW. (2012). Pengantar Psikologi Umum. Jakarta: Raja Grafindo

Yamin, Martinis dan Maisah. (2010). Standarisasi Kinerja Guru. Jakarta: Gaung Persada 
